\title{
Mateusz Gawliński
}

gawlinskim@wp.pl

Politechnika Warszawska, Filia w Płocku

\section{Engineering logistics in machine structure and exploitation Just-in-Time implementation process inside the enterprise}

\author{
Inżynieria logistyczna w budowie i eksploatacji maszyn \\ Proces wdrażania metody Just-in-Time w przedsiębiorstwie
}

This research paper contains the plan necessary to implement the Just-in-Time method. The target of research, analysis and implementation of JiT is an enterprise producing agricultural machines, cars, etc. The concept serves as an enhancement of the information and material process. This article demonstrates the process of introducing the selected tool inside a factory. It also highlights the benefits of JiT idea.

Stowa kluczowe:

Just-in-Time, JiT, engineering logistics, enterprise, production process optimization, machine structure and exploitation.

Opracowanie zawiera plan niezbędny do wdrażania metody Just-in-Time. Obiektem badań, analizy i wprowadzania JiT jest przedsiębiorstwo produkujące maszyny rolnicze, samochody itp. Omawiana koncepcja służy usprawnieniu procesów przepływu informacji i materiałów. W artykule przedstawiono proces wprowadzania wybranego narzędzia wewnątrz fabryki. Wyeksponowano też korzyści wynikające z idei JiT.

Key words:

Just-in-Time, JiT, inżynieria logistyczna, przedsiębiorstwo, optymalizacja procesów produkcyjnych, budowa i eksploatacja maszyn.

str. $18-22$

\section{Bibliografia}

Brzeziński, M. (2002). Organizacja i sterowanie produkcja. Warsaw: Placet. Ciesielski, M. (2006). Instrumenty zarządzania logistycznego. Warsaw: PWE.

Szymonik, A. (2011). Logistyka i zarządzanie łańcuchem dostaw (cz. 2). Warsaw: Difin. 